\title{
Monoclonal Antibodies Production, Diagnostic and Therapeutic Applications
}

\author{
Zainab M. Diab, AbdelhadyRagab, Tamer M. Soliman, MyadaHassan
}

Department of Clinical Pathology,Faculty of Medicine, Sohag University

Abstract

Introduction:Monoclonal antibody is an antibody that is specific for one antigen and is produced by a B-cell hybridoma. Hybridoma technology has been replaced by recombinant DNA technology and transgenic method (mice, plant and chickens). Once monoclonal antibodies for a given substance have been produced, they can be used to detect the presence and quantity of this substance and so monoclonal antibody has many diagnostic applications.

Aim of the work:To clarify the new methods for production of monoclonal antibodies and application of monoclonal antibodies in diagnostic and therapeutic approaches.

Conclusion:Hybridoma technology has been replaced by recombinant DNA technology and transgenic method (mice, plant and chickens). Once monoclonal antibodies for a given substance have been produced, they can be used to detect the presence and quantity of this substance and so monoclonal antibody has many diagnostic applications as in the analysis of cell surface and secreted molecules like CD molecules identification and identification of transcription factor FOXP3. Also, they have a role in the molecular genomics to identify the susceptible genes that predispose to development of autoimmune thyroid diseases.

Keywords:monoclonal antibodies, hybridoma technology, immune-diagnosis.

\section{Introduction}

Monoclonal antibody is an anti-body that is specific for one antigen and is produced by a B-cell hybridoma ${ }^{(\mathbf{1}, \mathbf{2})}$.

By the introduction of hybridoma technology monoclonal antibodies have come to play an enormous role in biologic research and applications. They offer the advantages of relative ease of the production and purification of large quantities of antibodies ${ }^{(2,3)}$.

Hybridoma technology has been replaced by recombinant DNA technology, transgenic mice and phage $\operatorname{display}^{(4,5)}$.

Monoclonal antibodies have had a profound impact on medicine by providing an almost limitless source of therapeutic and diagnostic reagents. Therapeutic use of mo-noclonal antibodies has become a major part of treatments in various diseases including transplantation, oncology, autoimmune, cardiovascular, and infectious diseases $^{(6)}$.

Antibodies are a key component of the adaptive immune response, playing a central role in the recognition of foreign antigens. The advent of monoclonal antibody tech-nology has made it possible to raise anti-bodies against specific antigens presented on the surfaces of tumors ${ }^{(7)}$.

Monoclonal antibody therapy is the use of monoclonal antibodies to specifically target cells. The main objective is stimula-ting the patient's immune system to attack the malignant tumor cells and the prevention of tumor growth by blocking specific cell receptors $^{(7)}$.

\section{Aim of the work:}

To clarify the new methods for production of monoclonal antibodies and clarify application of monoclonal antibodies in diagnostic and therapeutic approaches.

\section{Immunoglobulins:}

Immunoglobulins

(Antibodies)aregammaglobulinproteinst hat

arefoundinbloodandareusedbytheimmu nesystem toidentifyand neutralizeforeignobjects, areproducedbyakindofwhite bloodcell 
SOHAG MEDICAL JOURNAL

Vol. 22 No.3 October 2018

called a plasmacell ${ }^{(\mathbf{8})}$ in response to an immunogen ${ }^{(\mathbf{9})}$ Antibodiesareheavy $(\sim 150$ $\mathrm{kDa}$ )globularplasmaproteins. They areglycoproteins $^{(\mathbf{1 0})}$.

Thebasicfunctional

unitofeachantibodyisanimmunoglobulin (Ig)mono-merwhichisa"Y"-

shapedmoleculethatconsistsoffourpolyp eptide chains;twoidentical heavychainsandtwoidenticallightchains connectedbydisulfidebond ${ }^{\mathbf{1 1 1})}$.Eachchain iscomposedofstructuraldomains

calledIgdomains.

Thesedomainscontainabout70-

110aminoacids ${ }^{(\mathbf{1 2})}$.

Most Igs mediate several effector functions which include fixation of complement that results to lyses of cells and release of biologically active molecules, binding of various cells to facilitate specific functions by bound cells e.g. phagocytic cells, lymphocytes, platelets etc. Most effector functions of Abs are carried out after the Ab binds to $\mathrm{Ags}^{(\mathbf{9})}$.

Monoclonalantibodyisanantibodythat isspecificforoneantigen. It was firstly produced by hybridoma technologybut nowadays this hybridomatechnology has been replaced by recombinant DNA tech-nologyandtransgenicmethods ${ }^{(4)}$.

\section{I-Hybridoma Technology:}

Anormal,activated,antibodypro-ducing

Bcellisfusedwitha

myelomacell(cancerous

plasmacell)toproduceahydridecell,calle

d hybridoma. Thehyb-ridoma cellhastheproperties ofboththenormal, activatedantibodyproducing

cell(i.e.,thehybridoma cellsecretes antibodies)

andthecancerousmyelomacell[(i.e.,theh

ybridomacell

immortalized,(continuoustogrowindefin itely) ${ }^{(\mathbf{1 3})}$.

\section{II-Recombinant DNA technology:}

Theproductionofrecombinantmon

oclonal antibodiesinvolves technologies,referred to as repertoirecloning or phage display/yeast
display.Recombinantantibodyengineeri nginvolves theuseofvirusesor yeasttocreateantibodies, ratherthanmice ${ }^{(}$ 14). These techniquescan be used to enhance:the specificity with whichantibodies recognizeantigens, theirstabilityinvarious environmental conditio-ns, their therapeutic efficacy, and their detectability indiagnosticapplications $^{(\mathbf{1 5})}$.

III-Transgenic methods

Oneofthemostpromisingapproach-es totheproduction of therapeutic humanmonoclonalantibodiesis the creation of a mouse strainengineeredtoproducealargereperto ireofhuman antibodiesinthe absenceofmouseantibodies ${ }^{(\mathbf{1 6})}$.Nowchick encanbegeneticallyengineered toproducecancer intheireggwhites ${ }^{(17)}$

drugs Thegenesformonoclonalantibodycanbei nsertedintoplants andexpressedbythem. Cornisthemostpopularplantforthesepurp oses, buttobacco, tomatoes, potatoes, andricearealsobeingu sed $^{(18)}$

Throughouttheprogressionofmonoclonaldrugdevelopmentthere havebeenfourmajorantibodytypesdevelo ped: mu-rine,chimeric, humanized andhuman $^{(\mathbf{1 9 )}}$.

Humanized antibodies areproducedbygraftingmurine hypervariableaminoaciddomainsintohu manantibodies. Thisresultsin amoleculeofapproximately 95\% humanorigin ${ }^{(20)}$.

Humanmonoclonal antibodiesareproducedusingtransgenicm ice phagedisplaylibraries.Humanmonoclon alanti-bodiesareproducedby transferringhumanimmunoglobulingene sintothemurinegenome, after whichthetransgenic mouseisvaccinatedagainsttheimmunoglobulin, leading to the production of monoclonal antibodies Once monoclonal antibodies for a given 
SOHAG MEDICAL JOURNAL

Vol. 22 No.3 October 2018

substance have been produced, they can be used to detect the presence and quantity of this substance and so monoclonal antibody has many diagnostic applications ${ }^{(4)}$.

One of these most important applications is analysis of cell surface and secreted molecules like CD molecules identification and identification of transcription factor FOXP3 ${ }^{(7)}$.

The diagnosis of many infectious diseases relies on the detection of particular antigens or antibodies in the circulation or in tissues by use of monoclonal antibodies in immunoassays, for example bacteria disea-ses (Chlamydiae pneumonia) ${ }^{(21}$, 22), sero-typing niesseria meningitides and diagnosis of $\mathrm{H}$. pylori eradication 4 weeks after the end of treatment ${ }^{(23)}$.Viral diseases (rubella virus, hepatitis $\mathrm{E}$ virus and SARSCoVnucleocapsid protein $)^{(\mathbf{2 4},}{ }^{25)}$ and airborne fungi ${ }^{(\mathbf{1})}$.

In the field of molecular genomics the application of molecular biology with the help of monoclonal antibody has permitted identification of susceptibility genes that predispose to development of autoimmune diseases ${ }^{(\mathbf{2 6})}$.

There is a very important application in the field of molecular imaging especially in Immune-positron emission tomography (ImmunoPET). ImmunoPET combines the high sensitivity and resolution of a PET camera with the specificity of a mAb. immuno-PET enables the confirmation of tumor targeting and the quantification of $\mathrm{mAb}$ accumulation (in fact, radioactivity uptake). Thus, we can select patients who have the best chance to benefit from expensive $\mathrm{mAb}$-based therapy ${ }^{(27)}$.

Monoclonal antibodies have had a profound impact on medicine by providing an almost limitless source of therapeutic reagents. Its therapeutic use has become a major part of treatments in various diseases including transplantation, cancer therapy, autoimmune, cardiovascular, and infectious diseases ${ }^{(\mathbf{2 8})}$.

The first FDA-approved therapeutic monoclonal antibody was a murine IgG2a CD3 specific transplant rejection drug, Muromonab (OKT- 3), in 1986. This drug was found to be useful in solid organ transplant recipients who became steroid resistant. Currently, many FDA-approved therapies exist, and hundreds of therapies are undergoing clinical trials ${ }^{(\mathbf{2 8})}$.

Trastuzumab (Herceptin)isa mono-clonal antibody that interferes with the human epidermal growth factor (HER2/neu) receptor ${ }^{(29)}$.This increases the survival of people with cancer ${ }^{(30)}$. The original studies of trastuzumab showed that it improved survival in late-stage (metastatic) breast cancer $^{(29)}$.

Bevacizumab (trade name Avastin) is a humanized monoclonal antibody. It stops tumor growth by recognizing and blocking vascular endothelial growth factor (VEGF) ${ }^{(31)}$.It is approved by the U.S. Food and Drug Administration (FDA) for metastaticcancers ${ }^{(32)}$.

Rituximab (trade names Rituxan and MabThera) is a chimeric monoclonal antibody against the protein CD20, which is primarily found on the surface of $B$ cells. It is used in the treatment of many lymphomas, leukemias, and some autoimmune disorders ${ }^{(\mathbf{3 3})}$.

Also,it has been implicated as causing a Hepatitis E infection to become chronic (permanent) in a patient with a lymphoma. Hepatitis $\mathrm{E}$ infection is normally an acute (short-term) infection, suggesting the drug may have weakened the body's immune response to the virus ${ }^{(34)}$.

Also, there are other anti-CD20 monoclonal antibodies as ocrelizumab, humanized (90\%-95\% human) B celldepleting agent, ofAtumumab (HuMaxCD20) a fully human B cell-depleting agent and third-generation anti-CD20s have a glycoengineered $\mathrm{Fe}$ fragment 
SOHAG MEDICAL JOURNAL

Vol. 22 No.3 October 2018

(Fe) with enhanced binding to $\mathrm{Fe}$ gamma receptors, which increase ADCC (antibody dependent cellular cytotoxicity) ${ }^{(35)}$.

Radioimmunotherapy (RIT) involves the use of radioactively conjugated murine antibodies against cellular antigens. Most research currently involved their application to lymphomas, as these are highly radiosensitive malignancies ${ }^{\mathbf{( 3 6 )}}$.

Antibody-directed enzyme prodrug therapy (ADEPT) involves the application of cancer associated monoclonal antibodies which are linked to a drug-activating enzyme. Subsequent systemic administration of a non-toxic agent results in its conversion to a toxic drug and resulting in a cytotoxic effect which can be targeted at malignant cells. The clinical success of ADEPT treatments has been limited now ${ }^{(37)}$.

However, it does hold great promise and recent reports suggest that it will have a role in future oncological treatment. Monoclonal Antibodies may be used in autoimmune disease as in multiple sclerosis (MS) ${ }^{(38)}$ and in rheumatoid arthritis and systemic lupus erythematosus ${ }^{(39)}$.

Monoclonal antibody Anti-IgE monoclonal antibody also may be used for the treatment of asthma and other manifestations related to allergic diseases ${ }^{(\mathbf{4 0})}$. It has been demonstrated that systemic treatment with omalizumab reduced symptoms and caused improved quality of life in patients with moderate/severe allergic rhinitis $^{(41)}$.

Anti- $\mathrm{T}$ cell monoclonal antibodies derived from mouse $B$ cells and directed against human $\mathrm{T}$ cells, particularly those reacting with the CD3 marker (Muromonab CD3, OKT3), have been extensively used in the management of transplanted patients. These antibodies are predominantly used for the treatment of acute rejection. In addition, some groups of doctors use the monoclonal antibody as "induction" treatment imme-diately before transplantation to prevent rejection $^{(\mathbf{4 2})}$.

The role of complement system in inflammation has been well established. Inflammation is a cornerstone of the post-myocardial infarction. Also, during a heart bypass procedure, the "Complement activation" causes an inflammatory response that can lead to side effects such as chest pain, heart attack, stroke, heart failure, or death ${ }^{(\mathbf{4 3})}$.

One such agent which causes complement inhibition is Pexelizumab. Pexelizumab, a recombinant humanized single chain monoclonal antibody to $\mathrm{C} 5$, blocks the conversion of $\mathrm{C} 5$ to $\mathrm{C} 5 \mathrm{a}$ and accordingly inhibits C5b-9. It is an engineered monoclonal antibody fragment designed to inhibit complement-mediated tissue damage associated with reperfusion injury and inflammation that occurs during open heart surgery.

Some trials in the last years have evaluated the role of Pexelizumab in patients undergoing Coronary Artery Bypass Graft surgery and also in the treatment of acute myocardial infarction $^{(\mathbf{4 3})}$.

New prophylactic and therapeutic strategies to combat human infections with highly pathogenic avian influenza (HPAI) H5NI viruses are needed. Neutralizing anti-H5NI human monoclonal antibodies ware generated and tested their efficacy for prophylaxis and therapy in a murine model of infection $^{(44)}$.

Some researchers are trying to use a new method of rapidly producing highly targeted monoclonal antibodies to develop a diagnostic test as well as a temporary therapy to stave off the HINl (swine flu) virus ${ }^{(45)}$.

Many diseases of the eye, such as agerelated macular degeneration (AMD) 
SOHAG MEDICAL JOURNAL Vol. 22 No.3 October 2018

and diabetic retinopathy, damage the retina and cause blindness when blood vessels around the retina grow abnormally and leak fluid, causing the layers of the retina to separate. This abnormal growth is caused by VEGF, so bevacizumab has been successfully used to inhibit VEGF and slow this growth $^{(46)}$.

Drug abuse continues to be a major national and worldwide problem, and effective treatment strategies are badly needed. Antibodies are promising therapies for the treatment of medical problems caused by drug abuse (e.g. treatment of phencyclidine or methamphetamine overdose), with several candidates in preclinical and early clinical trials ${ }^{(47)}$.

\section{Conclusion}

- In addition to its diagnostic applications monoclonal antibody have many therapeutic applications and one of the most important of these therapeutic applications is the use of monoclonal antibody in the treatment of cancer.

- Also Mab are used in the treatment of auto-immune diseases like multiple sclerosis (MS), rheumatoid arthritis and systemic lupus erythematosus.

- Mab are used also in the treatment of myocardial infarction and in coronary artery bypasses graft surgery.

- Mab are used in the treatment of some viral disease like West Nile virus and $\mathrm{H} 5 \mathrm{NI}$ influenza infection.

\section{References:}

1. Abbas AK, and, Litchman AH. Basic Immunology "Function and disorder of the immune system". . Williams and Wilkins $2^{\text {nd }}$ Ed:. 2007:279-83.

2. Singh S, Kumar NK, Dwiwedi P, Charan J, Kaur R, Sidhu P, et al. Monoclonal Antibodies: A Review. Current clinical pharmacology. 2018;13(2):85-99.

3. William P. Fundamental immunology, . Lippincott Raven 4th Ed:. 1998:101-4.
4. Hudson PJ, and, Souriau C. Engineered antibodies. 9: 129-134. Nat Med. 2003;9:129-34.

5. Chen Y, Kim SH, Shang Y, Guillory J, Stinson J, Zhang Q, et al. Barcoded sequencing workflow for high throughout digitization of hybridoma antibody variable domain sequences. Journal of immunological methods. 2018;455:8894.

6. Nissim A, and, Chernajovsky Y. Historical development of monoclonal antibody therapeutics. Exp Pharmacol. 2008;181:3-18.

7. Janeway CA. Immunobiology, Garland Science. 6th Ed: 1653-9. Janeway C.A. and Charles G. Immunobiology. Garland Science $5^{\text {th }}$ Ed. 2005:1639-46.

8. Eleonora $\mathrm{M}$, and, Papavasiliou $\mathrm{F}$. Recombination and the Evolution of the Adaptive Immune System. PLoS Biology. 2003:(1): 16.

9. Pleass RJ, Moore SC, Stevenson L, Hviid L. Immunoglobulin M: Restrainer of Inflammation and Mediator of Immune Evasion by Plasmodium falciparum Malaria. Trends in parasitology 2016;32(2)::108-19.

10.Yang J, 1, Shen M, H. Polyethylene glycol-mediated cell fusion. . Methods Mol Biol. 2006;325:59-66.

11.Dunn AL. Pathophysiology, diagnosis and prevention of arthropathy in patients with haemophilia. Haemophilia. 2011;17(4):571-8.

12.Lafeber FP, Miossec P, Valentino LA. Physiopathology of haemophilic arthropathy. Haemophilia. 2008;14(Suppl 4):3-9.

13.Ahlberg A. Haemophilia in Sweden. VII. Incidence, treatment and prophylaxis of arthropathy and other musculoskeletal manifestations of haemophilia A and B. Acta orthopaedica Scandinavica Supplementum.2010:Suppl 77:3-132.

14.Nieuwenhuizen L, Roosendaal G, Coeleveld K, Lubberts E, Biesma DH, Lafeber FP, et al. Haemarthrosis stimulates the synovial fibrinolytic system in haemophilic mice. Thromb Haemost. 2013;110(1):173-83.

15.Acharya SS, Kaplan RN, Macdonald D, Fabiyi OT, DiMichele D, Lyden D. Neoangiogenesis contributes to the 
SOHAG MEDICAL JOURNAL

Vol. 22 No.3 October 2018 development of hemophilic synovitis. Blood. 2011;117(8):2484-93.

16. Madhok R, Bennett D, Sturrock RD, Forbes CD. Mechanisms of joint damage in an experimental model of hemophilic arthritis. Arthritis Rheum.2011;31(9):1148-55.

17.Jansen NW, Roosendaal G, Bijlsma JW, Degroot J, Lafeber FP. Exposure of human cartilage tissue to low concentrations of blood for a short period of time leads to prolonged cartilage damage: an in vitro study. Arthritis Rheum. 2007;56(1):199-207.

18. Roosendaal G, Vianen ME, Marx JJ, van den Berg HM, Lafeber FP, Bijlsma JW. Blood-induced joint damage: a human in vitro study. Arthritis Rheum.2013;42(5):1025-32.

19.Stern M, and, Herrmann R. Overview of monoclonal antibodies in cancer therapy: present and promise. . Crit Rev Oncol Hemato. 2005;154:11-29.

20.Narkbunnam N, Sun J, Hu G, Lin FC, Bateman TA, Mihara M, et al. IL-6 receptor antagonist as adjunctive therapy with clotting factor replacement to protect against bleeding-induced arthropathy in hemophilia. J Thromb Haemost. 2013;11(5):881-93.

21.Geisberger R, Lamers M, Achatz G. "The riddle of the dual expression of IgM and IgD". . Immunology 2006;118(4):889-98. .

22.Roosendaal G, Vianen ME, Wenting MJ, van Rinsum AC, van den Berg HM, Lafeber FP, et al. Iron deposits and catabolic properties of synovial tissue from patients with haemophilia. The Journal of bone and joint surgery British volume.2008;80(3):540-5.

23. Roosendaal G, Lafeber FP. Pathogenesis of haemophilic arthropathy. Haemophilia. 2006;12 Suppl 3:117-21.

24.Raffini L, Manno C. Modern management of haemophilic arthropathy. British journal of haematology. 2007;136(6):777-87.

25.Valentino LA. Blood-induced joint disease: the pathophysiology of hemophilic arthropathy. J Thromb Haemost. 2010;8(9):1895-902.

26. Mihara M, Moriya Y, Kishimoto T, Ohsugi Y. Interleukin-6 (IL-6) induces the proliferation of synovial fibroblastic cells in the presence of soluble IL-6 receptor. British journal of rheumatology.2013;34(4):321-5.

27. Hashizume M, Hayakawa N, Mihara M. IL-6 trans-signalling directly induces RANKL on fibroblast-like synovial cells and is involved in RANKL induction by TNF-alpha and IL-17. Rheumatology. 2008;47(11):1635-40.

28.Nissim A, and, Chernajovsky Y. Historical development of monoclonal antibody therapeutics. . Exp Pharmacol 2008;181:3-18.

29.Feldman BM, Funk SM, Bergstrom BM, Zourikian N, Hilliard P, van der Net $J$, et al. Validation of a new pediatric joint scoring system from the International Hemophilia Prophylaxis Study Group: validity of the hemophilia joint health score. Arthritis care \& research. 2011;63(2):223-30.

30.Santin AD, Bellone S, Roman J, McKenney J, and, Pecorelli S. Trastuzumab treatment in patients with advanced or recurrent endometrial carcinoma overexpressing $\mathrm{HER}_{2} /$ neu. Int J Gynaecol Obstet 2008;102 (2):128-31.

31.Folkman J, Shing Y. Angiogenesis. The Journal of biological chemistry.2006;267(16):10931-4.

32.Joseph-Silverstein J, Rifkin DB. Endothelial cell growth factors and the vessel wall. Seminars in thrombosis and hemostasis.2010;13(4):504-13.

33. Ortega N, Jonca F, Vincent S, Favard C, Ruchoux MM, Plouet J. Systemic activation of the vascular endothelial growth factor receptor KDR/flk-1 selectively triggers endothelial cells with an angiogenic phenotype. The American journal of pathology.2004;151(5):121524.

34.Gerber HP, Condorelli F, Park J, Ferrara N. Differential transcriptional regulation of the two vascular endo-thelial growth factor receptor genes. Flt-1, but not Flk$1 / \mathrm{KDR}$, is up-regulated by hypoxia. The Journal of biological chemistry.2010;272(38):23659-67.

35.Patel V, Mihatov N, Cooper N, Stasi R, Cunningham-Rundles $\mathrm{S}$, and, et al. Long-term responses seen with rituximab m patients with ITP. Community Oncology 2007;4(2):107. 
SOHAG MEDICAL JOURNAL

Vol. 22 No.3 October 2018

36.Diaz-Torne C, Schumacher HR, Yu X, Gomez-Vaquero C, Dai L, Chen LX, et al. Absence of histologic evidence of synovitis in patients with Gulf War veterans' illness with joint pain. Arthritis Rheum. 2007;57(7):1316-23.

37.Krenn V, Morawietz L, Burmester GR, Kinne RW, Mueller-Ladner U, Muller $\mathrm{B}$, et al. Synovitis score: discrimination between chronic low-grade and highgrade synovitis. Histopathology. 2006;49(4):358-64.

38.Krenn V, Morawietz L, Konig B, Otto M, Kriegsmann J, Kopenik A, et al. Low-grade/high-gradesynovitis: synovitis-score as a gold standard?. Der Orthopade. 2006;35(8):853-9.

39.Pessler F, Chen LX, Dai L, GomezVaquero C, Diaz-Torne C, Paessler ME, et al. A histomorphometric analysis of synovial biopsies from individuals with Gulf War Veterans' Illness and joint pain compared to normal and osteoarthritis synovium. Clinical rheumatology. 2008;27(9):1127-34.

40.Della Beffa C, Slansky E, Pommerenke C, Klawonn F, Li J, Dai L, et al. The relative composition of the inflammatory infiltrate as an additional tool for synovial tissue classification. PLoS One. 2013;8(8):e72494.

41.Krenn V, Morawietz L, Haupl T, Neidel J, Petersen I, Konig A. Grading of chronic synovitis--a histopathological grading system for molecular and diagnostic pathology. Pathology, research and practice. 2002;198(5):317-25.

42.Ribbens C, Andre B, Marcelis S, Kaye O, Mathy L, Bonnet V, et al. Rheumatoid hand joint synovitis: gray-scale and power Doppler US quantifications following anti-tumor necrosis factoralpha treatment: pilot study. Radiology. 2003;229(2):562-9.

43. Reiche BE, Ohrndorf S, Feist E, Messerschmidt J, Burmester GR, Backhaus M. Power doppler ultrasound is useful for prediction of re-therapy with rituximab in rheumatoid arthritis. Arthritis care \& research. 2013.

44.Iagnocco A, Epis O, Delle Sedie A, Meenagh G, Filippucci E, Riente L, et al. Ultrasound imaging for the rheumatologist. XVII. Role of colour Doppler and power Doppler. Clinical and experimental rheumatology. 2008;26(5):759-62.

45.Szkudlarek M, Court-Payen M, Strandberg C, Klarlund M, Klausen T, Ostergaard M. Power Doppler ultrasonography for assessment of synovitis in the metacarpophalangeal joints of patients with rheumatoid arthritis: a comparison with dynamic magnetic resonance imaging. Arthritis Rheum. 2001;44(9):2018-23.

46.Dougados M, Devauchelle-Pensec V, Ferlet JF, Jousse-Joulin S, D'Agostino MA, Backhaus M, et al. The ability of synovitis to predict structural damage in rheumatoid arthritis: a comparative study between clinical examination and ultrasound. Annals of the rheumatic diseases. 2013;72(5):665-71.

47.Naredo E, Batlle-Gualda E, GarciaVivar ML, Garcia-Aparicio AM, Fernandez-Sueiro JL, Fernandez-Prada $\mathrm{M}$, et al. Power Doppler ultrasonography assessment of entheses in spondyloarthropathies: response to therapy of entheseal abnormalities. The Journal of rheumatology. 2010;37(10):2110-7. 
SOHAG MEDICAL JOURNAL

Vol. 22 No.3 October 2018
Monoclonal Antibodies Production, Diagnostic MyadaHassan 